\title{
The Importance of Environmental English Public Signs to Xiong'an New Area's Ecological Environment in China
}

\author{
Junhong Tang, Jiancheng Wang \\ Foreign Language Department, Baoding University, Baoding, China \\ Email: jessytang99@163.com
}

How to cite this paper: Tang, J.H. and Wang, J.C. (2017) The Importance of Environmental English Public Signs to Xiong'an New Area's Ecological Environment in China. Open Journal of Ecology, 7, 682-687. https://doi.org/10.4236/oje.2017.713047

Received: August 21, 2017

Accepted: December 24, 2017

Published: December 27, 2017

Copyright (C) 2017 by authors and Scientific Research Publishing Inc. This work is licensed under the Creative Commons Attribution International License (CC BY 4.0).

http://creativecommons.org/licenses/by/4.0/

\begin{abstract}
With the establishment and development of Xiong'an New Area in China, more foreign industries and visitors will be attracted to come here. Investigations made in our study show that the environmental English public signs are very important. They can offer directions for foreigners who can't understand Chinese well because they have these three functions: indication, suggestion and prohibition. In order to help Xiong'an New Area play its "eco card", the translators are supposed to attach great importance to the translation of environmental English public signs.
\end{abstract}

\section{Keywords}

Xiong'an New Area in China, Environmental English Public Signs, Eco Card

\section{Introduction}

"Public Signs" is a kind of public language appearing in public places. It intends to convey some special meaning to the public and it is a special style of communication [1].

The translation of public signs reflects the civilization and the culture level of a city, so it becomes more and more important. Meanwhile, environmental problems, energy problems, ecological balance problems, etc. become a common concern with the global environmental deterioration. Creating a good natural and friendly cultural environment will become one of the focuses of the whole world. The purposes of environmental English public signs are to better publicize the concept of environmental protection, strengthen readers' awareness of environmental protection and arouse the reader to protect the environment with practical action. Most importantly, they can offer directions for foreigners who 
are not able to understand Chinese well. In this way, it is expected to create a harmonious ecological environment and discourage actions hostile to the environment.

On April 1 $1^{\text {st }}, 2017$, the Central Committee of the Communist Party of China and the State Council decided to set up a Hebei new security zone, Xiong'an New Area [2]. It is another new district with national significance after Shenzhen Special Economic Zone and Shanghai Pudong New Area. It is a historic strategic choice for carrying out the Millennium Program and state affairs. There are seven important tasks in Xiong'an construction and planning. The first two tasks are related to Environmental protection industry. Xiong'an New Area strives to become a green city.

In "Opinions on expanding opening to the outside world and actively use foreign capital adopted by the State Council" [3], it is clearly stated that implementation of foreign investment policy to build an open area of New Development Zone is very important. With the establishment and development of Xiong'an New Area, it will attract more and more foreign visitors and industries from every corner of the world coming into China. With the increasing number of the foreigners, the environmental English public signs will become more important, because they offer foreigners more information on where and how to do to be friendly with the local environment in English which foreigners can understand easily.

\section{Ecology Is the Key Point in the Development of Xiong'an New Area}

Yunzhong Liu, dean of Development Strategy Research Center and Regional Economic Research Department of the State Council Development Research Center, believes that Xiong'an New Area in China plays a critical role in the process of constructing world class urban agglomerations in Jing-Jin-Ji. There are three points. First, Xiong'an New Area is an important base in developing high-end high-tech industry, and it will absorb and gather a great deal of innovation factor resources and become a new momentum of economic growth and an important innovation driven place. Second, Xiong'an New Area will be the benchmark and model in construction ecological and intelligent city. It will improve the world influence and competitiveness of Jing-Jin-Ji. Third, Xiong'an New Area will be the benchmark and model of governance structure innovation in metropolitan areas, urban agglomerations and urban continuous belts in the world.

\subsection{The New District Planning Should Play "Eco Card"}

The green development concept should be integrated into the planning, compilation, approval, implementation, supervision and assessment of the integrated development plan [4]. The most important thing is to form a joint effort to promote the construction of ecological civilization, and all kinds of behavior subjects, especially the government's public decision-making, should be green. 
The development of Xiong'an New Area is a Millennium Project and a major national event. Chairman Xi Jinping pointed out that we should use the most advanced concepts and world-class design to create an innovative development demonstration zone for the implementation of the new concept of development. As we can see, the ecology has been placed in an important position in the construction of Xiong'an New Area. Green development concept should and must be integrated in the process of planning, preparation, approval, implementation, supervision and assessment.

\subsection{With Culture as the Driving Force, It Will Become a Whole City of Tourism Integrating History with Modern Times}

One of the important positions of Xiong'an New Area is to share part of the function of Beijing. Universities, research institutions and even government departments will move from Beijing to Xiong'an New Area, which will make a large number of elite permanent residents live here. Where there are people, there must be a new culture. The elite from Beijing will also bring forth a new culture of Xiong'an New Area. This is the core driving force of the tourism industry in the new district. The connotation of Xiong'an culture can be divided into the following three parts: First, there are a lot of reformers like Jiao Zhang, Bei Liu, Kuangyin Zhao, Zhidong Zhang, Dazhao Li. They all played important roles in different social change in different historical periods. Second, there are a great number of heroes and heroines such as Ke Jing, Sui Mao, Zheng Wei, Mulan Hua. Third, there are lots of poets and writers like Yu Han, Hanqing Guan, Xueqin Cao. All of these famous people contribute to the tourism of Xiong'an New Area and it will attract more and more foreigners to come to China. As a result, the environmental English public signs will be very critical and important for the improvement of ecological environment.

\section{The Important Functions of Environmental English Public Signs in the Ecological Development of Xiong'an New Area}

English is an international language. The environmental English public signs play very critical roles in the ecological development of Xiong'an New Area. They affect many aspects of people's life. With the rapid development of Xiong'an New Area in China, a lot of visitors, industries and workers will probably come into here. In order to offer more information for foreigners about environment protection, the existence of Environmental English public signs will be very necessary because they have the following functions: indicative function, suggestive function and prohibitive function.

\subsection{The Indicative Function}

The indicative function of environmental English public signs offers considerate information, and there is no prohibition [5]. Its main purpose is to help foreigners feel easily and comfortably which contributes to the ecological development of Xiong'an New Area. 
Such public signs as "Trashcan on the right", "Please feel free to smoke in the lounge", "Save water", "NON RECYCLABLE" are indicative environmental English public signs. They will help foreigners get enough information on where to throw their garbage and where to smoke.

\subsection{The Suggestive Function}

The suggestive environmental English public signs can be widely used in many cases. They have no strict restriction and they offer a lot of information. Public signs like "Recycle bins are located in the area between tower A (basement floor) and B", "Look for the blue rectangular containers", "Thank you for helping out our environment", "Just like Santa Claus and the Easter Bunny, the cleaning fairy DOES NOT EXIST!!", "Please keep area clean and tidy at all times.", "Please keep this office tidy and use the bins provided" [6] etc. play an very important function in helping foreigners keeping the environment clean and clear.

\subsection{The Prohibitive Function}

The prohibitive environmental English public signs clearly put forward requirements and standards for the public's behavior. There are some restrictions. The language is direct but not rude and impolite. Such public signs as "Quiet, please.", "Keep off the grass" are typical environmental English public signs. They keep people from doing some things which is harmful to the environment.

The environmental English public signs are not only used in social life, but also used in industries, agriculture and so on. Its purpose is to make Xiong'an New Area develop in the right orbit. With the development of society and economy, environmental pollution and ecological energy crisis have become urgent and urgent matter to be solved. Environmental protection English public signs follows the footsteps of the times, reflecting the common existence of mankind and the earth and the sustainable development vision. In addition, it also shows the urgency of human survival in terms of positive action and propaganda of environmental protection which reflects the coordinated development of human survival and environmental protection.

\section{Some Statistics on the Importance of Environmental English Public Signs}

In order to test the importance of environmental English public signs, we made an investigation on it.

We interviewed 56 travelers who came from different countries. The following four questions were asked. 1) Is it easy for you to find trash cans in a place where there are no environmental English public signs are? 2) Is it easy for you to find trash cans in a place where there are environmental English public signs? 3) Do you think environmental English public signs are necessary especially in scenic spots or industrial area? 4) Is it easy for you to understand environmental Chinese public signs? The statistics of the four questions are listed in Tables 1-3. 
Table 1. Comparisons between environmental English and Chinese public signs.

\begin{tabular}{cccccc}
\hline questions & Very Easy (\%) & Easy (\%) & So So (\%) & Difficult (\%) & Very Difficult (\%) \\
\hline 1 & $4 \%$ & $7 \%$ & $3 \%$ & $20 \%$ & $66 \%$ \\
2 & $80 \%$ & $15 \%$ & $5 \%$ & 0 & 0 \\
\hline
\end{tabular}

Table 2. The necessity of environmental English public signs.

\begin{tabular}{cccccc}
\hline question & Very necessary (\%) & $\begin{array}{c}\text { Necessary } \\
(\%)\end{array}$ & $\begin{array}{c}\text { So So } \\
(\%)\end{array}$ & Unnecessary (\%) & Completely unnecessary (\%) \\
\hline 3 & $52 \%$ & $40 \%$ & $3 \%$ & $3 \%$ & $2 \%$ \\
\hline
\end{tabular}

Table 3. Foreigners' Understanding for environmental English public signs.

\begin{tabular}{cccccc}
\hline question & Very Easy (\%) & Easy (\%) & So So (\%) & Difficult (\%) & Very Difficult (\%) \\
\hline 4 & $2 \%$ & $9 \%$ & $30 \%$ & $41 \%$ & $18 \%$ \\
\hline
\end{tabular}

The above four tables show that it is difficult for foreigners to understand environmental Chinese public signs. Environmental English public signs will be very helpful for foreigners to get enough directions to find where to drop litter or to smoke, etc., so environmental English public signs are necessary and helpful in offering more directions for foreigners.

\section{Conclusions}

English is an international language. Translation aims at expressing the content and thought of the original language text clearly and explicitly, so as to eliminate the gap between languages and cultural differences. So, Environmental English public signs translation plays an important role in building a green and low-carbon blueprint for sustainable development. Chinese and English have their own unique cultural background and origin, so only on the basis of mastering and applying translation language and combining with the purpose of environmental protection translation can we realize and develop the purpose of environmental English translation.

With regard to the functions of environmental English public signs and the different languages and cultures, the translation of the public signs is very critical and important. So many people coming from different fields, translator, research institutions, related government departments, media, will be responsible for it [7]. They need cooperate with each other and take their own responsibilities.

Environmental English public signs are an important part of social language reflecting the rapid development of the Chinese government and the public in the current industrialized society. With the rapid development of Xiong'an New Area, there will be more and more industries and foreigners gathering in Xiong'an New Area. Most importantly, the new district planning plays "eco card" [8], which means environmental protection is one of the key factors in the process of its development. As a result, the environmental English public signs 
become very important and necessary. By paying attention to environmental protection, we try to achieve the coordinated development of material civilization and spiritual civilization construction.

\section{Acknowledgements}

The paper is under the social science fund project of Hebei Province, Study on the Construction of Harmonious English Teaching Environment in Internet Plus Era (HB16JY004). All the project members made their contributions to the paper. I also thank all my friends and classmates, especially Zhiqin Shang, a foreign tourist guide, who made the investigation possible and reliable.

\section{References}

[1] Li, Y. and Xu, J. (2011) Spoken English for Tourism. University of International Business and Economics Press, Beijing.

[2] Li, X. and Wang, B.Y. (2017) Strengthen Ecological Restoration and Environmental Protection, Realizing Harmonious Relation between the Human Being and the Nature. Special Zone Economy, No. 4, 125-126.

[3] http://mp.weixin.qq.com/s? _ biz=MzIxNjUxOTQ2Mw\%3D\%3D\&chksm=978683cf a0f10ad933d6ee945a6871064abdadb3d73dce2d3bc8e7c5f7ebc226a8870b6f156a\&idx $=1 \& \mathrm{mid}=2247484807 \&$ scene $=21 \& \mathrm{sn}=21 \mathrm{c} 8827 \mathrm{cdfb} 973 \mathrm{e} 89 \mathrm{c} 3 \mathrm{e} 7405 \mathrm{f} 18 \mathrm{a} 76 \mathrm{e} 8$

[4] Wang, Y. and Bao, C.K. (2017) China Environment News. http://www.cfej.net/

[5] Liu, Q.L. (2008) English Tour Guide Words of Hebei Classical Tourist Attractions. China Travel \& Tourism Press, Beijing.

[6] Wang, X.Y. (2014) Practical Guide English. Peking University Press, Beijing.

[7] Du, C.L. (2014) Agents Roles in Translation-Taking Translation of Public Signs in Changzhou as an Example. Journal of Jiangsu Teachers University of Technology, No. 1, 42-45.

[8] Zhang, W.H. and Gao, Y.R. (2017) The Observation and Development of China. http://theory.people.com.cn/GB/82288/83853/index.html 